\section{Mansfield in the Dock}

That Senator Mansfield should have become the focus for so much discontent about the arrangements for the support of research and development in the United States is one of the great ironies of the past few months, for he is a liberal man who would by instinct have been found on the side of the angels. The amendment to the military appropriations bill for the financial year just ended which now carries his name, and which requires that the Department of Defense should no longer support research not directly linked with its immediate goal, was aimed not at the universities but at the Pentagon. This is the spirit in which he was entirely within his rights to protest last week (see page 433) that it had been the Administration's responsibility to modify its budget for the current financial year so as to ensure that worthy projects should not be foolishly abandoned. This, indeed, is one of the grounds for believing that the Administration has bungled the support of basic science. Senator Mansfield is quite right in saying that the Office of Science and Technology should have been able to predict the consequences of his amendment and urge a corresponding increase of the budget of the National Science Foundation. Although there may be something in the view that the NSF would have been dealt with even less generously had not the Office of Science and Technology struggled on its behalf during the budgetmaking process just under a year ago, there is no doubt that the office was caught napping by the Mansfield Amendment.

There remains the question of whether Mr Mansfield

\section{Quick Change}

THE death of Mr Iain Macleod, Chancellor of the Exchequer until a week ago, has cast a long shadow. One of its consequences is that Mr Geoffrey Rippon has been snatched from the Ministry of Technology to take over the negotiations for entry into the European Economic Community, the post which Mr Anthony Barber occupied until he in turn became Chancellor of the Exchequer. It will be interesting to see how $\mathrm{Mr}$ Barber makes out in his onerous office-with economic and fiscal change so much at the centre of the new government's policy, his appointment must be something of a gamble. It is also somewhat doubtful whether Mr Rippon will be happier in Brussels than he was likely to have been at the Ministry of Technology -he is an able man for whom neither job can have fitted like a glove. His successor at the Ministry of Technology, Mr John Davies, is more likely to be able to come quickly to grips with the projects and problems which have survived from the time of the Labour Government, but the reputation for abrasiveness, even rudeness, which he earned when director of the Confederation of British Industry as recently as two is right in his assertion that the Department of Defense has no useful job to do in basic research entirely unrelated to its military objectives. To be sure, there are many ways in which it would be simpler for everybody in academic life if the universities were independent of military support, for strictly peaceful research. Moreover, too much is probably made of the belief that if the Pentagon's support for basic research should disappear, its links with academic science will wither entirely away. It is, of course, unthinkable that a modern military machine should dispense without good and thorough advice on military matters from academic scientists, and there is no reason why this should not continue even if the Mansfield Amendment should remain. This is the sense in which striking a balance between military and other support for civilian research is not so much a great issue of principle as a practical matter of good administration. The truth is that the National Science Foundation is not yet large enough or skilled enough to take over the diverse projects that the Pentagon has abandoned. Moreover, if it is to become the chief source of support for academic science-a worthy objective-one of the most urgent needs is that it should assume responsibility for the high energy physics now under the umbrella of the AEC and even for some of the space research sponsored by NASA. So will Senator Mansfield direct his formidable political powers at these objectives before subjecting the Pentagon to the full rigours of his amendment? That might well be the best outcome of the present row.

years ago must cast doubt on his capacity to win round people to his way of thinking except by beating them over the head. His appointment may become an interesting test of whether high office can be counted on to bring out the best in people. A few weeks should be enough to show which way the wind is blowing.

Of all the loose ends to be picked up, the question of how to manage the future of the nuclear power industry is the most urgent, and the manner in which $\mathrm{Mr}$ Davies deals with this should serve excellently to show whether he is still the fierce advocate of government non-intervention that he used to be in his happygo-lucky days at the CBI. The immediate issue is the future of establishments such as the Atomic Energy Research Establishment at Harwell and the other parts of the Atomic Energy Authority which are still responsible for the design of reactors and the building of prototypes such as that of the fast reactor now well advanced. It is clearer now than a few years ago that it will be dangerous for the government to wash its hands of research and development as cleanly as had 